\title{
Altered elimination of antipyrine in patients with acute viral hepatitis ${ }^{1}$
}

\author{
D. A. BURNETT ${ }^{2}$, A. J. BARAK, D. J. TUMA, AND M. F. SORRELL 3,4 \\ From the Liver Study Unit, Department of Internal Medicine, Veterans Administration Hospital and the \\ University of Nebraska Medical Center, Omaha, Nebraska, U.S.A.
}

SUMMARY The plasma half-life and clearance of antipyrine was investigated in patients during the acute phase and again during the recovery phase of viral hepatitis. Each patient served as his own control, thereby eliminating genetic factors and minimising environmental factors that cause large interindividual variations in antipyrine elimination rates. Liver function tests, antipyrine, half-life, plasma clearance, and the apparent volume of distribution were determined in the acute and recovery period. It was found that the apparent volume of distribution of antipyrine did not change in five of six patients as they recovered. Five of the six patients showed prolonged plasma half-lives and decreased plasma clearance of the drug at the time of acute illness and these parameters reached normal values during recovery. The plasma half-life and clearance of the drug did not correlate with biochemical indices of liver function in the acute or recovery phase. This demonstration supports the concept that drug metabolism is frequently impaired in liver disease.

The liver is the primary metabolic site of drugs and other foreign compounds. Hepatic drug metabolism is thought to be abnormal in liver disease, but failure to eliminate genetic and environmental variables from study groups has made confirmation of this hypothesis difficult. This has led to conflicting reports concerning the effect of liver disease on drug metabolism. In patients with varying degrees of liver injury some studies have shown the metabolic rate of certain drugs to be impaired (Levi et al., 1968; Mawer et al., 1972; Powell and Axelsen, 1972; Thomson et al., 1973; Andreasen et al., 1974; Klotz et al., 1974, 1975; Branch et al., 1975; McHorse et al., 1975); other studies have failed to confirm this observation (Weiner et al., 1954; Brodie et al., 1959; Marcus and Kapadia, 1964; Nelson, 1964; Maxwell et al., 1972).

In this investigation, acute viral hepatitis, a generally self-limiting liver disease, was selected for study. Each patient was studied when acutely ill and

\footnotetext{
${ }^{1}$ Veterans Administration Project No. 0804-04.

${ }^{2}$ Present address: University of California, San Francisco School of Medicine, Department of Medicine, San Francisco, California 94143, U.S.A.

${ }^{3}$ This investigator was supported in part by an Academic Career Development Award No. AM 70316 from the National Institutes of Arthritis, Metabolism and Digestive Diseases.

Address for reprint requests: Dr. M. F. Sorrell, Veterans Administration Hospital, 4101 Woolworth Avenue, Omaha, Nebraska 68105, U.S.A.

Received for publication 10 February 1976
}

again during recovery, thus eliminating genetic variables. Antipyrine was used as the model drug to evaluate hepatic drug metabolism because it is distributed rapidly in total body water, completely absorbed when given orally, less than $10 \%$ protein bound (Soberman, et al., 1942), believed to be metabolised almost entirely by the liver (Brodie and Axelrod, 1950; Woodbury and Finge, 1975), and has few associated side effects. Recent studies (Vesell et al., 1973; Huffman et al., 1974) have validated the use of antipyrine clearance as an index of hepatic drug metabolism in man.

\section{Methods}

STUDY SUBJECTS AND PROTOCOL

Three men and three women, aged 19-44 years (mean 29 years), $55-115 \mathrm{~kg}$ in weight (mean $80.5 \mathrm{~kg}$ ), with clinical and biochemical evidence of acute viral hepatitis were studied. The diagnosis was confirmed by liver biopsy in two of six subjects (W.W., K.M.). None had taken drugs, including diuretics, for four weeks before the onset of their illness. No drugs except multivitamins were given during the study period. Patients could eat what they liked and walk about if they wished to do so. During hospitalization, each patient was studied when acutely ill and again when there was clinical and laboratory evidence of improving liver function. In this manner, each 
patient served as his own control, thereby eliminating genetic factors and minimizing environmental factors that cause large interindividual variations in antipyrine elimination rates. One patient was further studied as an outpatient one month after the initial onset of hepatitis. Selected clinical and laboratory characteristics of the individual patients are listed in Table 1.

After informed consent, antipyrine was given orally in a dose of $10 \mathrm{mg} / \mathrm{kg}$ body weight. Venous blood was collected in citrated tubes at three, six, nine, 12, and 24 hours after administration of the drug. The blood was centrifuged, the plasma separated, and stored $\left(-30^{\circ} \mathrm{C}\right)$ until assayed.

\section{ANALYTIC AND PHARMACOKINETIC}

PROCEDURES

The plasma was assayed for antipyrine by the precipitation method of Brodie et al. (1949). The anti- pyrine half-life $\left(\mathrm{T}_{2}^{\frac{1}{2}}\right)$ and extrapolated zero time plasma concentration $\left(\mathrm{C}_{0}\right)$ were determined by linear regression analysis. The apparent volume of distribution (aVd) was determined by dividing the total dose of antipyrine received by each subject by the $\mathrm{C}_{0}$. Plasma antipyrine clearance (C1) was calculated from the formula.

$$
\text { Antipyrine clearance }(\mathrm{C} 1)=\frac{0.693 \times \mathrm{aVd}}{\mathrm{T}_{\frac{1}{2}}^{\frac{1}{2}}}
$$

where $0.693 / \mathrm{T}_{2} \frac{1}{2}$ is the elimination rate constant $(\mathrm{k})$. Statistical analyses were conducted using Student's $t$ test for paired samples.

\section{Results}

Table 2 demonstrates the alterations of antipyrine metabolism in six patients with acute viral hepatitis. The apparent volume of distribution was not altered

\begin{tabular}{|c|c|c|c|c|c|c|c|c|}
\hline Subject & $\begin{array}{l}\text { Age } \\
\text { (yr), } \\
\text { sex, }\end{array}$ & $\begin{array}{l}T \frac{1}{2} \\
(h)\end{array}$ & $H B_{S} A g$ & $\begin{array}{l}\text { Bilirubin } \\
(m g / d l)\end{array}$ & $\begin{array}{c}S G O T \\
(I U / m l)\end{array}$ & $\begin{array}{c}S G P T \\
(I U / m l)\end{array}$ & $\begin{array}{l}\text { Prothrombin } \\
\text { time } \\
\text { patient/control } \\
(s)\end{array}$ & $\begin{array}{l}\text { Albumin } \\
(g / d l)\end{array}$ \\
\hline 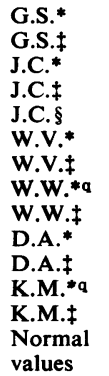 & $\begin{array}{l}33 \mathrm{M} \\
32 \mathrm{~F} \\
44 \mathrm{M} \\
20 \mathrm{M} \\
27 \mathrm{~F} \\
19 \mathrm{~F}\end{array}$ & $\begin{array}{r}17.1 \\
10.7 \\
9.0 \\
9.1 \\
10.7 \\
26.0 \\
17.7 \\
20.7 \\
13.9 \\
24.5 \\
9.7 \\
45.0 \\
10.8 \\
\\
6-20\end{array}$ & $\begin{array}{l}- \\
+ \\
+ \\
+\end{array}$ & $\begin{array}{r}10.3 \\
5.0 \\
12.6 \\
3.8 \\
1.2 \\
33.2 \\
4.2 \\
5.6 \\
2.0 \\
9.4 \\
1.1 \\
11.0 \\
4.4 \\
\\
<1.2\end{array}$ & $\begin{array}{c}177 \\
62 \\
225 \\
60 \\
18 \\
700 \\
25 \\
750 \\
12 \\
- \\
- \\
87 \\
25 \\
\\
<40\end{array}$ & $\begin{array}{c}410 \\
194 \\
-\quad \\
127 \\
12 \\
1090 \\
16 \\
750 \\
-\quad \\
2010 \\
13 \\
54 \\
42 \\
<35\end{array}$ & $\begin{array}{l}12 \cdot 5 / 12 \\
11 / 11 \\
11 \cdot 5 / 11 \\
12 / 11\end{array}$ & $\begin{array}{l}4.0 \\
3.9 \\
4 \cdot 1 \\
3.4\end{array}$ \\
\hline
\end{tabular}

Table 1 Selected clinical and laboratory characteristics of patients with hepatitis given antipyrine

*Acute stage. $\ddagger$ During recovery. § One month after onset of illness. 9 Diagnosis confirmed by liver biopsy. SGOT: serum glutamic oxaloacetate transaminase. SGPT: serum pyruvic transaminase. $\mathrm{HB}_{\mathbf{s}} \mathrm{Ag}$ : hepatitis B surface antigen.

\begin{tabular}{|c|c|c|c|c|}
\hline Subject & $\begin{array}{l}\text { Body weight } \\
(k g)\end{array}$ & $\begin{array}{l}\text { Apparent volume } \\
\text { distribution } \\
(I)\end{array}$ & $\begin{array}{l}\text { Plasma half-life } \\
\text { (h) }\end{array}$ & $\begin{array}{l}\text { Plasma clearance } \\
(\mathrm{ml} / \mathrm{min})\end{array}$ \\
\hline
\end{tabular}

Table 2 Pharmacokinetic characteristics of antipyrine removal in patients with acute and resolving viral hepatitis

*Acute stage. $\ddagger$ During recovery. § One month after onset of illness. 
during the course of the illness except for K.M. who showed an $18 \%$ decrease during recovery. Five of the six patients showed a prolonged plasma half-life and decreased plasma clearance of antipyrine when acutely ill, as compared with values obtained during recovery $(P<0.02)$. There was no evident relation between abnormalities of the routine liver function test and the antipyrine $\mathrm{T}_{\frac{1}{2}}$ or clearance rates. Although our patients were studied when biochemical parameters indicated incomplete resolution of the inflammatory process, all antipyrine half-lives obtained during recovery were within the published range of normal (Vesell and Page, 1969). One patient (J.C.) was studied a third time one month after the onset of her illness at a time when routine liver function tests had returned to normal. Plasma $T_{\frac{1}{2}}$ and clearance rates were essentially unchanged (Table 2) from values observed during recovery.

\section{Discussion}

In patients with liver disease, previous studies of drug metabolism have shown prolonged plasma halflives of diazepam (Klotz et al., 1975), meperidine (Klotz et al., 1974; McHorse et al., 1975), phenylbutazone (Levi et al., 1968), isoniazid (Levi et al., 1968), lidocaine (Thomson et al., 1973), prednisone (Powell and Axelsen, 1972), amylobarbitone (Mawer et al., 1972), and antipyrine (Andreasen et al., 1974; Branch et al., 1975). Other studies have failed to demonstrate delayed plasma disappearance of phenylbutazone (Weiner et al., 1954), chlorpromazine (Maxwell et al., 1972), digoxin (Marcus and Kapadia, 1964), tolbutamide (Nelsen, 1964), and antipyrine (Brodie et al., 1959). Factors which may be responsible for such disparity in results include varying degrees of liver injury with difficulty in quantifying the extent of liver disease, interindividual variation in drug metabolism, and recent progress in the understanding of the pharmacokinetics of drug metabolism. Although we did not attempt to correlate the metabolism of antipyrine with other drugs, previous attempts to do so have been unsuccessful (Davies and Thorgeirsson, 1971).

The important finding in this study was the demonstration that antipyrine clearance was impaired in acute viral hepatitis and improved during recovery. We attribute this decrease of antipyrine elimination to impaired intrahepatic drug metabolism. Antipyrine is believed to be metabolised primarily by the liver (Brodie and Axelrod, 1950; Woodbury and Finge, 1975); less than $5 \%$ is excreted unchanged in the urine (Huffman et al., 1974). Hepatic blood flow in acute viral hepatitis has been observed to be normal (Preisig et al., 1966). Hence, it is unlikely that changes in hepatic blood flow explain these findings. Furthermore, the elimination rate of a drug such as antipyrine, with a low blood/liver extraction ratio, is independent of minor variations in hepatic blood flow (Rowland, 1972). The in vitro demonstration of reduced activity of constituents of the hepatic mixed function oxidase system (Doshi $e t$ al., 1972; Schoene et al., 1972) in acute hepatitis, with return to normal or above normal level during recovery, further supports this concept of impaired intrahepatic drug metabolism. Expansion of the volume of distribution may prolong the antipyrine half-life without changing the rate of drug elimintion; however, our subjects exhibited no change in aVd during repeated studies while $\mathrm{C} 1$ rates increased and $T_{1} \frac{1}{2}$ decreased upon recovery (Table 2). These observations would support the concept of impaired hepatic drug metabolism as the cause of prolonged antipyrine half-life and decreased clearance in acute liver injury.

Our failure (Table 1) to show a correlation between the $T_{2} \frac{1}{2}$ and plasma clearance of antipyrine on one hand and biochemical indicators or liver function on the other, is in agreement with the findings of Klotz et al. (1975) who studied the removal of diazepam in hepatitis. Similar data have been reported for lidocaine (Thomson et al., 1973) and carbenicillin (Hoffman et al., 1970). Decreased serum albumin concentrations and/or abnormal prothrombin times have been shown to mirror the prolonged $\mathrm{T}_{2} \frac{1}{2}$ of phenylbutazone (Levi et al., 1968), amylobarbital (Mawer et al., 1972), and antipyrine (Branch et al., 1975). Our demonstration of impaired drug clearance in a limited number of patients with normal serum albumin concentrations and prothrombin times, suggests that no test, or group of tests, are of value in predicting drug elimination rates in subjects with modest degrees of liver injury.

\section{References}

Andreasen, P. B., Ranek, L., Statland, B. E., and Tygstrup, N. (1974). Clearance of antipyrine-dependence of quantitative liver function. European Journal of Clinical Investigation, 4, 129-134.

Branch, R. A., Herbert, C. M., and Read, A. E (1975). Determinants of serum antipyrine half-lives in patients with liver disease. Gut, 14, 569-573.

Brodie, B. B., and Axelrod, J. (1950). The fate of antipyrine in man. Journal of Pharmacology and Experimental Therapeutics, 98, 97-104.

Brodie, B. B., Axelrod, J., Soberman, R., and Levy, B. B. (1949). The estimation of antipyrine in biological materials. Journal of Biological Chemistry, 179, 25-29.

Brodie, B. B., Burns, J. J., and Weiner, M. (1959). Metabolism of drugs in subjects with Laennec's cirrhosis. Medicina Experimentalis (Basel), 1, 290-292.

Davies, D. S., and Thorgeirsson, S. S. (1971). Mechanism of hepatic drug oxidation and its relationship to individual differences in rates of oxidation in man. Annals of the New York Academy of Sciences, 179, 411-420. 
Doshi, J., Luisada-Opper, A., and Leevy C. M. (1972). Microsomal pentobarbital hydroxylase activity in acute viral hepatitis. Proceedings of the Society for Experimental Biology and Medicine, 140, 492-495.

Hoffman, T. A., Cestero, R., and Bullock, W. E. (1970). Pharmacodynamics of carbenicillin in hepatic and renal failure. Annals of Internal Medicine, 73, 173-178.

Huffman, D. H., Shoeman, D. W., and Azarnoff, D. L. (1974). Correlation of the plasma elimination of antipyrine and the appearance of 4-hydroxyantipyrine in the urine of man. Biochemical Pharmacology, 23, 197-201.

Klotz, U., Avant, G. R., Hoyumpa, A., Schenker, S., and Wilkinson, G. R. (1975). The effects of age and liver disease on the disposition and elimination of diazepam in adult man. Journal of Clinical Investigation, 55, 347-359.

Klotz, U., McHorse, T. S., Wilkinson, G. R., and Schenker, S. (1974). The effect of cirrhosis on the disposition and elimination of meperidine in man. Clinical Pharmacology and Therapeutics, 16, 667-675.

Levi, A. J., Sherlock, S., and Walker, D. (1968). Phenylbutazone and isoniazid metabolism in patients with liver disease in relation to previous drug therapy. Lancet, 1, 1275-1279.

McHorse, T. S., Wilkinson, G. R., Johnson, R. F., and Schenker, S. (1975). Effects of acute viral hepatitis in man on the disposition and elimination of meperidine. Gastroenterology, 68, 775-780.

Marcus, F. I., and Kapadia, G. G. (1964). The metabolism of tritiated digoxin in cirrhotic patients. Gastroenterology, 47, 517-524.

Mawer, G. E., Miller, N. E., and Turnberg, L. A. (1972). Metabolism of amylobarbitone in patients with chronic liver disease. British Journal of Pharmacology, 44, 549-560.

Maxwell, J. D., Carrella, M., Parkes, J. D., Williams, R. Mould, G. P., and Curry, S. H. (1972). Plasma disappearance and cerebral effects of chlorpromazine in cirrhosis. Clinical Science, 43, 143-151.

Nelson, E. (1964). Rate of metabolism of tolbutamide in test subjects with liver disease or with impaired renal function. American Journal of Medical Sciences, 248, 657-659.

Powell, L. W., and Axelsen, E. (1972). Corticosteroids in liver disease: studies on the biological conversion of prednisone to prednisolone and plasma protein binding. Gut, 13, 690-696.

Preisig, R., Rankin, J. G., Sweeting, J., and Bradley, S. E. (1966). Hepatic hemodynamics during viral hepatitis in man. Circulation, 34, 188-197.

Rowland, M. (1972). Application of clearance concepts to some literature data on drug metabolism in the isolated perfused liver preparation and in vivo. European Journal of Pharmacology, 17, 352-356.

Schoene, B., Fleischmann, R. A., Remmer, H., and von Oldershausen, H. F. (1972). Determination of drug metabolizing enzymes in needle biopsies of human liver. European Journal of Clinical Pharmacology, 4, 65-73.

Soberman, R., Brodie, B. B., Levy, B. B., Axelrod, J., Hollander, V., and Steele, J. M. (1942). The use of antipyrine in the measurement of total body water in man. Journal of Biological Chemistry, 179, 31-42.

Thomson, P. D., Melmon, K. L., Richardson, J. A., Cohn, K., Steinbrunn, W., Cudikee, R., and Rowland, M. (1973) Lidocaine pharmacokinetics in advanced heart failure, liver disease and renal failure in humans. Annals of Internal Medicine, 78, 499-508.

Vesell, E. S., Lee, C. J., Passananti, G. T., and Shively, C. A. (1973). Relationship between plasma antipyrine half-lives and hepatic microsomal drug metabolism in dogs. Pharmacology, 10, 317-328.

Vesell, E. S., and Page, J. G. (1969). Genetic control of the phenobarbital-induced shortening of plasma antipyrine half-lives in man. Journal of Clinical Investigation, 48, 2202-2209.

Weiner, M., Chenken, T., and Burns, J. J. (1954). Observations on the metabolic transformation and effects of phenylbutazone in subjects with hepatic disease. American Journal of the Medical Sciences, 228, 36-39.

Woodbury, D. M., and Fingl, E. (1975). Analgesic-antipyretics, anti-inflammatory agents, and drugs employed in the therapy of gout. In The Pharmacological Basis of Therapeutics, 5th edn. p. 325, Edited by L. S. Goodman and A. Gilman. Macmillan: New York. 